\title{
DFT Studies of NH-Cl Hydrogen Bond of Amino Acid Hydrochloride Salts in Ion Channels
}

\author{
Marjan Moridi, ${ }^{1}$ Setareh Shekarsaraei ${ }^{1}$ and Nasser L. Hadipour ${ }^{1, *}$ \\ ${ }^{1}$ Department of Chemistry, Tarbiat Modares University, Tehran, Iran \\ * Corresponding author: E-mail: hadipour@modares.ac.ir \\ Phone: (+886)2 27898679
}

Received: 22-08-2015

\begin{abstract}
Quantum chemical calculations were made, to study $\mathrm{NH}-\mathrm{Cl}$ hydrogen bonds of two amino acid hydrochloride salts called alanine and threonine. The Nuclear Magnetic Resonance and Nuclear Quadrupole Resonance parameters for nitrogen and chlorine were calculated via four functionals such as, B3LYP, M062X, M06L, and CAM-B3LYP and by applying the $6-311++\mathrm{G}(\mathrm{d}, \mathrm{p})$ basis set. One of the functionals produced more accurate results. Geometry optimization was performed using the M062X/6-31++G(d,p) method, and Natural Bond Orbitals analysis was performed by applying the M062X/6-311++G(d,p) level. This study examined Nuclear Magnetic Resonance and Nuclear Quadrupole Resonance parameters with changes in structure from monomer to pentamer and investigated correlations between Natural Bond Orbitals parameters and Nuclear Magnetic Resonance or Nuclear Quadrupole Resonance parameters. The Natural Bond Orbitals parameters were used to investigate changes in structural parameters along with crystal development.
\end{abstract}

Keywords: Chemical shift; Quadrupolar coupling constant; Nuclear magnetic resonance; Density functional theory.

\section{Introduction}

Properties of the hydrogen bond are well known because it has been the subject of many investigations. ${ }^{1-6}$ Hydrogen bonds have an important role in biological systems ${ }^{7}$ and in the determination of structures and properties of large molecules in biochemistry, chemistry, and materials science. ${ }^{8-12}$ The detection of molecular structure in Ion Channels is possible by studying the hydrogen bonds. Amino acids are components of ion channels. These channels that are located in cell membranes guide electrical current through the membrane. ${ }^{13-15}$ Ion channels play a major role in biological processes and when defective can cause significant health problems such as Bartter's syndrome, cystic fibrosis, startle disease, and myotonia. ${ }^{13}$ For example, a defect in alanine, histidine, threonine, aspartic acid, and cysteine amino acids leads to mutation or change in CLCNKB $^{\mathrm{a}}$ ion channel that causes type III of Bartter's syndrome. ${ }^{16}$ Thus, the study of the structural and binding environments of inorganic atoms within these channels has important implications. The knowledge of the structure of these channels can be increased by studying the hydrogen bonds. Thus, the aim of the study of interactions in amino acids is to determine any change in structure to recognize any defects in these channels. Most information regarding the structure of ion channels has been obtained by X-ray crystallography, ${ }^{17,18}$ but in this study, the goal is to evaluate any changes in the structure of these channels by using solid-state nuclear magnetic resonance (SSNMR) and nuclear quadrupole resonance (NQR). ${ }^{19}$ In general, the study of biological molecules, such as proteins, use the NMR spectroscopy technique that is beneficial for determining structure in both the solution ${ }^{20,21}$ and solid states. ${ }^{22,23}$ Solid-state NMR has been considered a lot over the past several decades, ${ }^{24,25}$ including studies on proteins, ${ }^{26}$ polymers, inorganic materials, ${ }^{27}$ as well as clays and minerals. ${ }^{28}$ More accurate information can be obtained by using NQR data in addition to NMR data. ${ }^{29}$ We can understand any changes in

\footnotetext{
${ }^{a}$ The CLCNKB gene belongs to the CLC family of genes, which provide instructions for making chloride channels. These channels, which transport negatively charged chlorine atoms (chloride ions), play a key role in a cell's ability to generate and transmit electrical signals. Some CLC channels regulate the flow of chloride ions across cell membranes, while others transport chloride ions within cells. The CLCNKB gene provides instructions for making a chloride channel called $\mathrm{ClC}-\mathrm{Kb}$. The official name of this gene is »chloride voltagegated channel $\mathrm{Kb}$.« CLCNKB is the gene's official symbol.
} 
the nuclear environment with changes in NMR and NQR parameters and thus find any changes in the structure of amino acids. In this study, we also find the most accurate functional from B3LYP, M062X, M06L, and CAM$\mathrm{B}^{2} \mathrm{LYP}^{30}$ to calculate NMR and NQR parameters. M062X is very convenient to use in biological structures, and M06L has produced highly accurate results in such systems. ${ }^{31,32}$

\section{1. NMR Tensor Convention}

In SSNMR, we have to calculate chemical shielding tensor parameters to obtain information about interactions. In Haeberlen-Mehring-Spiess (HMS) convention, ${ }^{33,34}$ three NMR parameters can be calculated by using three principal components of the chemical shielding tensor, $\sigma_{\mathrm{XX}}, \sigma_{\mathrm{YY}}$ and $\sigma_{\mathrm{ZZ}}$. The relationship between three principal components of the chemical shielding tensor must always be as follows: $\left|\sigma_{\mathrm{ZZ}}-\sigma_{\text {iso }}\right| \geq\left|\sigma_{\mathrm{XX}}-\sigma_{\text {iso }}\right| \geq \mid \sigma_{\mathrm{YY}}$ $-\sigma_{\text {iso }}$. The NMR parameters defined below:

$$
\begin{aligned}
& \sigma_{\text {iso }}=\frac{\sigma_{X X}+\sigma_{Y Y}+\sigma_{Z Z}}{3} \\
& \Delta \sigma=\sigma_{Z Z}-\frac{\sigma_{X X}+\sigma_{Y Y}}{2} \\
& \eta=\frac{\sigma_{Y Y}-\sigma_{X X}}{\sigma_{Z Z}-\sigma_{\text {iso }}}
\end{aligned}
$$

where $\sigma_{\text {iso }}$ is the isotropic shielding value, $\Delta \sigma$ is the shielding tensor anisotropy, and $\eta$ is shielding tensor asymmetry, which must always have a value between zero and one.

\section{2. Nuclear Electric Quadrupolar Interaction}

Nuclei with nuclear spin quantum number (I) larger than $1 / 2$, are quadrupolar nuclei. For these nuclei, the electric charge is not spherically symmetrical, and they have an electric quadrupole moment, Q. The electrostatic field gradient tensor (EFG) arising from the electron distribution, and it will couple with $\mathrm{Q}$ at the nuclear center, so these nuclei can be studied by NQR spectroscopy. Principal components of EFG tensor must be arranged in this way: $\mathrm{q}_{\mathrm{ZZ}} \geq \mathrm{q}_{\mathrm{YY}} \geq \mathrm{q}_{\mathrm{XX}}$.
The quadrupolar coupling constant $\left(\mathrm{C}_{\mathrm{Q}}\right)$ and the asymmetry parameter $\left(\eta_{\mathrm{Q}}\right)$, represent the magnitude of quadrupole interaction and the symmetry around the nucleus, respectively, where e is the charge on an electron, $Q$ is the nuclear electric quadrupole moment, and h is Planck's constant:

$$
\begin{aligned}
& \mathrm{C}_{Q}(\mathrm{MHz})=\frac{\mathrm{e} \times \mathrm{q}_{Z Z} \times \mathrm{Q}}{h} \\
& \eta_{Q}=\frac{\mathrm{q}_{X X}-\mathrm{q}_{Y Y}}{\mathrm{q}_{Z Z}}, 1 \geq \eta_{\mathrm{Q}} \geq 0
\end{aligned}
$$

The other aim of this study was to show the correlation between the structural parameters and Natural Bond Orbitals (NBO) data. Analysis of the hydrogen bonding was required to achieve this goal. The A-H-B hydrogen bond is a combination of two effects: ${ }^{35}$ (1) The hyperconjugative effect that decreases the strength of the $\mathrm{A}-\mathrm{H}$ bond thereby increasing the length of the A-H bond. This effect is the electron charge transfer from the lone pair of the Lewis base, $\mathrm{B}$, to the antibonding orbital, $\sigma^{*}$, of the $\mathrm{A}-\mathrm{H}$ bond. This interaction, $\mathrm{n}_{\mathrm{B}} \rightarrow \sigma_{\mathrm{AH}}{ }^{*}$, can be calculated as the second-order perturbation theory energy (Eq. (6)): $:^{36}$

$$
\mathrm{E}_{N B O}=\mathrm{E}^{(2)}=\Delta \mathrm{E}\left(\mathrm{n}_{\mathrm{B}} \rightarrow \sigma_{\mathrm{AH}}^{*}\right)=\frac{\left.-2<\mathrm{n}_{\mathrm{B}}|\mathrm{F}| \sigma_{\mathrm{AH}}^{*}\right\rangle^{2}}{\varepsilon\left(\sigma_{\mathrm{AH}}^{*}\right)-\varepsilon\left(\mathrm{n}_{\mathrm{B}}\right)}
$$

where $<\mathrm{n}_{\mathrm{B}}|\mathrm{F}| \sigma_{\mathrm{AH}}{ }^{*}>$ is the Fock matrix element, and $\varepsilon\left(\sigma_{\mathrm{AH}}{ }^{*}\right)-\varepsilon\left(\mathrm{n}_{\mathrm{B}}\right)$ is the energy difference between these two orbitals. (2) The rehybridization effect that leads to an increase in $\mathrm{A}-\mathrm{H}$ bond strength also decreases the $\mathrm{A}-\mathrm{H}$ bond length. This effect is a concept of Bent's rule, which speaks to the hybridization of the central atom (A) in the molecule $\mathrm{X}-\mathrm{A}-\mathrm{Y}$. A provides hybridized atomic orbitals that form A's part of its bond to $\mathrm{X}$ and to $\mathrm{Y}$. Bent's rule says that as we change the electronegativity of $\mathrm{X}$ and/or $\mathrm{Y}$, A will tend to rehybridize its orbitals such that more s character will be placed in those orbitals and be directed towards the more electropositive substituent. ${ }^{37}$

\section{Methods}

Calculations of molecular orbital were carried out using the density functional theory (DFT) method. All
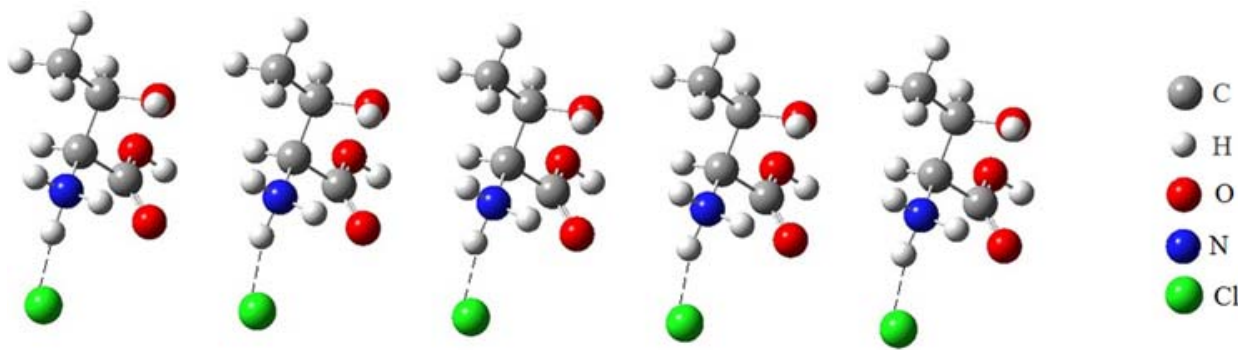

Figure 1. Hydrogen-bonding network of threonine hydrochloride cluster optimized at M06-2X / 6-31++G(d,p) level. 


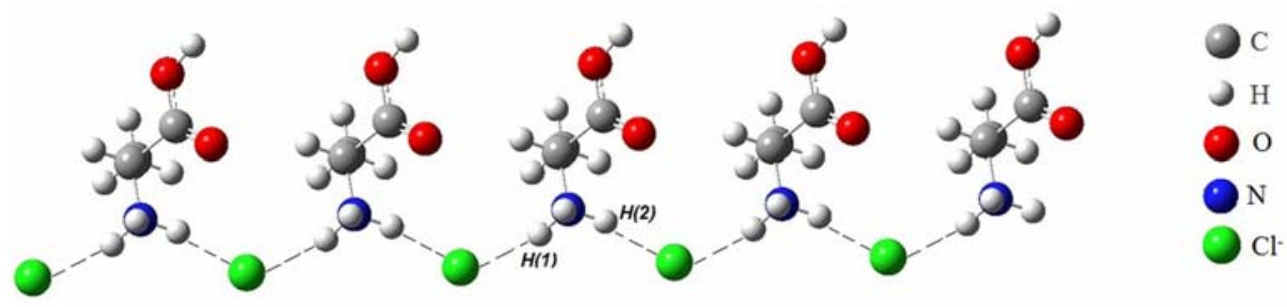

Figure 2. Hydrogen-bonding network of alanine hydrochloride cluster optimized at M06-2X / 6-31++G(d,p) level.

DFT calculations were performed using the GAMESS electronic structure package. ${ }^{38}$ Alanine hydrochloride atomic coordinates and unit cell parameters were derived from X-ray or neutron diffraction studies of Di Blasio et al. ${ }^{39}$ while threonine hydrochloride atomic coordinates from the X-ray structures of L. Bryce et al. ${ }^{25}$ were used. The geometry optimizations were performed using M06$2 \mathrm{X}$ method with 6- $31++\mathrm{G}(\mathrm{d}, \mathrm{p})$ basis set to find the position of hydrogen atoms in the stable state of the system from monomer to pentamer in threonine hydrochloride (Figure 1) and alanine hydrochloride (Figure 2). Reports show that this method is more accurate for matching to experimental data. ${ }^{30}$

The models closely approximate the real crystal. The study of large structures is not possible because of the limited capacity of computer systems. So in this study the addition of monomer units to the initial monomer were continued until pentamer because the NQR parameters approach a steady limit (see Tables 1-4). Calculations of the chlorine and nitrogen nuclear magnetic shielding and EFG tensors were based on these models and by using four functionals, B3LYP, M06-2X, M06L, CAM-B3LYP, and 6-311++G(d,p) basis set. The M06-2X/6-311++G(d,p) method was used for calculating NBO parameters.

\section{Results and Discussion}

\section{1. Investigation of NQR Parameters}

The models for amino acid hydrochloride salts, shown in Figures 1 and 2, were utilized in quantum chemical calculations of the NMR interaction tensors. Results presented in Tables 1-4 show that molecular interactions significantly affect the electric field and its gradient in these two hydrochloride clusters, and also indicate that the quadrupolar coupling constant of chlorine and nitrogen nuclei decrease from dimmer to pentamer in all functionals. Reduction in the $\mathrm{C}_{\mathrm{Q}}$ value is connotative of an increment in hydrogen bond strength. ${ }^{40}$ According to Tables 2 and 4, a decrease in $\mathrm{C}_{\mathrm{Q}}$ in alanine hydrochloride salt is more significant than a decrease in $\mathrm{C}_{\mathrm{Q}}$ in another salt, which could be as a result of hydrogen bond forma-

Table 1. Calculated chlorine-35 quadrupolar and chemical shift data for various Alanine hydrochloride clusters.

\begin{tabular}{|c|c|c|c|c|c|}
\hline Model & Functional & $\sigma_{\text {iso }}(p p m)$ & $\Delta \sigma(p p m)$ & $\left|\mathrm{C}_{\mathrm{Q}}\right|$ (MHz) & $\left|\eta_{Q}\right|$ \\
\hline \multirow[t]{4}{*}{ Monomer } & B3LYP & 999.78 & 187.45 & 15.96 & 0.03 \\
\hline & M062X & 1018.51 & 172.77 & 15.51 & 0.04 \\
\hline & M06L & 1001.26 & 162.32 & 14.28 & 0.05 \\
\hline & CAM-B3LYP & 1014.52 & 172.63 & 15.07 & 0.03 \\
\hline \multirow[t]{4}{*}{ Dimer } & B3LYP & 1018.05 & 157.55 & 12.25 & 0.59 \\
\hline & M062X & 1034.18 & 146.70 & 11.81 & 0.62 \\
\hline & M06L & 1014.35 & 142.25 & 10.91 & 0.62 \\
\hline & CAM-B3LYP & 1030.95 & 146.77 & 11.56 & 0.59 \\
\hline \multirow[t]{4}{*}{ Trimer } & B3LYP & 947.37 & 116.17 & 7.41 & 0.68 \\
\hline & M062X & 958.53 & 115.58 & 6.58 & 0.73 \\
\hline & M06L & 958.17 & 103.99 & 6.83 & 0.72 \\
\hline & CAM-B3LYP & 962.42 & 112.32 & 6.94 & 0.69 \\
\hline \multirow[t]{4}{*}{ Tetramer } & B3LYP & 946.32 & 117.85 & 7.22 & 0.72 \\
\hline & M062X & 956.99 & 119.30 & 6.60 & 0.77 \\
\hline & M06L & 951.17 & 104.22 & 6.72 & 0.75 \\
\hline & CAM-B3LYP & 961.27 & 113.87 & 6.77 & 0.72 \\
\hline \multirow[t]{4}{*}{ Pentamer } & B3LYP & 946.90 & 116.80 & 7.20 & 0.73 \\
\hline & M062X & 958.96 & 117.62 & 6.66 & 0.79 \\
\hline & M06L & 943.15 & 112.42 & 6.73 & 0.75 \\
\hline & CAM-B3LYP & 961.62 & 113.35 & 6.76 & 0.73 \\
\hline Exp. $\left({ }^{35} \mathrm{Cl}\right)$ & & $(913.4 \pm 5$ & - & $6.4 \pm 0.1$ & $-0.75 \pm 0.06$ \\
\hline
\end{tabular}


tion. In an alanine hydrochloride salt, the nitrogen atom can contribute to hydrogen bonding with a chlorine atom of a neighboring molecule, but it is not possible for a nitrogen atom in the threonine hydrochloride salt, and it contributes to one hydrogen bond. So, we expected that all changes in NQR parameters were larger in an alanine hydrochloride salt. The asymmetry parameter $\left(\eta_{\mathrm{Q}}\right)$ can show the information about the symmetry of the nuclear environment. The asymmetry parameter of chlorine in both hydrochloride salts increases regularly, but for nitrogen atoms this parameter decreases from dimmer to pentamer. All changes were investigated from dimmer to pentamer, because the molecule is still in a gas phase rather than a crystalline state in a monomer situation.

Consequently, we can use NMR and NQR parameters to evaluate any changes in the structure of amino

Table 2. Calculated nitrogen quadrupolar and chemical shift data for various Alanine hydrochloride clusters.

\begin{tabular}{|c|c|c|c|c|c|}
\hline Model & Functional & $\sigma_{\text {iso }}(\mathbf{p p m})$ & $\Delta \sigma(\mathbf{p p m})$ & $\left|\mathrm{C}_{\mathrm{Q}}\right|$ (MHz) & $m_{Q} l$ \\
\hline \multirow[t]{4}{*}{ Monomer } & B3LYP & 187.53 & 13.79 & 1.73 & 0.30 \\
\hline & M062X & 194.10 & 12.87 & 1.70 & 0.29 \\
\hline & M06L & 196.38 & 10.45 & 1.64 & 0.25 \\
\hline & CAM-B3LYP & 193.13 & 12.97 & 1.73 & 0.31 \\
\hline \multirow[t]{4}{*}{ Dimer } & B3LYP & 187.13 & 12.35 & 1.60 & 0.96 \\
\hline & M062X & 193.74 & 13.74 & 1.56 & 0.96 \\
\hline & M06L & 196.47 & 8.56 & 1.51 & 0.94 \\
\hline & CAM-B3LYP & 192.64 & 12.51 & 1.60 & 0.97 \\
\hline \multirow[t]{4}{*}{ Trimer } & B3LYP & 189.69 & 9.54 & 1.45 & 0.95 \\
\hline & M062X & 195.98 & 11.08 & 1.41 & 0.95 \\
\hline & M06L & 198.00 & 6.5 & 1.49 & 0.87 \\
\hline & CAM-B3LYP & 195.01 & 9.86 & 1.46 & 0.94 \\
\hline \multirow[t]{4}{*}{ Tetramer } & B3LYP & 189.89 & 9.53 & 1.44 & 0.93 \\
\hline & M062X & 196.37 & 10.23 & 1.40 & 0.93 \\
\hline & M06L & 198.86 & 4.89 & 1.48 & 0.85 \\
\hline & CAM-B3LYP & 195.20 & 9.85 & 1.45 & 0.92 \\
\hline \multirow[t]{4}{*}{ Pentamer } & B3LYP & 189.88 & 9.32 & 1.44 & 0.93 \\
\hline & M062X & 197.00 & 9.43 & 1.40 & 0.93 \\
\hline & M06L & 199.54 & 4.50 & 1.48 & 0.85 \\
\hline & CAM-B3LYP & 195.21 & 9.65 & 1.45 & 0.91 \\
\hline
\end{tabular}

Table 3. Calculated chlorine-35 quadrupolar and chemical shift data for various threonine hydrochloride clusters.

\begin{tabular}{|c|c|c|c|c|c|}
\hline Model & Functional & $\sigma_{\text {iso }}(\mathbf{p p m})$ & $\Delta \sigma(\mathbf{p p m})$ & $\left|\mathrm{C}_{\mathrm{Q}}\right|(\mathrm{MHz})$ & $m_{\mathrm{Q}}$ \\
\hline \multirow[t]{4}{*}{ Monomer } & B3LYP & 1052.65 & 145.73 & 9.79 & 0.22 \\
\hline & M062X & 1084.44 & 112.74 & 8.68 & 0.20 \\
\hline & M06L & 1028.77 & 144.64 & 8.77 & 0.21 \\
\hline & CAM-B3LYP & 1078.63 & 113.24 & 8.66 & 0.22 \\
\hline \multirow[t]{4}{*}{ Dimer } & B3LYP & 1044.78 & 121.91 & 8.15 & 0.33 \\
\hline & M062X & 1070.92 & 100.25 & 7.22 & 0.33 \\
\hline & M06L & 1030.05 & 117.61 & 7.37 & 0.31 \\
\hline & CAM-B3LYP & 1066.07 & 98.69 & 7.22 & 0.34 \\
\hline \multirow[t]{4}{*}{ Trimer } & B3LYP & 1048.63 & 111.08 & 7.43 & 0.35 \\
\hline & M062X & 1071.60 & 96.06 & 6.58 & 0.34 \\
\hline & M06L & 1034.63 & 112.99 & 6.73 & 0.32 \\
\hline & CAM-B3LYP & 1068.10 & 92.15 & 6.61 & 0.35 \\
\hline \multirow[t]{4}{*}{ Tetramer } & B3LYP & 1048.74 & 108.96 & 7.31 & 0.35 \\
\hline & M062X & 1071.27 & 95.40 & 6.47 & 0.35 \\
\hline & M06L & 1033.93 & 115.59 & 6.62 & 0.33 \\
\hline & CAM-B3LYP & 1068.29 & 90.76 & 6.51 & 0.35 \\
\hline \multirow[t]{4}{*}{ Pentamer } & B3LYP & 1048.87 & 107.42 & 7.26 & 0.36 \\
\hline & M062X & 1072.88 & 88.82 & 6.37 & 0.36 \\
\hline & M06L & 1040.94 & 114.29 & 6.01 & 0.33 \\
\hline & CAM-B3LYP & 1068.40 & 89.84 & 6.44 & 0.36 \\
\hline Exp. $\left({ }^{35} \mathrm{Cl}\right)$ & & $(920.37 \pm 10$ & - & $5.4 \pm 0.1$ & $0.94 \pm 0.02$ \\
\hline
\end{tabular}


Table 4. Calculated nitrogen quadrupolar and chemical shift data for various threonine hydrochloride clusters.

\begin{tabular}{|c|c|c|c|c|c|}
\hline Model & Functional & $\sigma_{\text {iso }}(p p m)$ & $\Delta \sigma(p p m)$ & $\left|\mathrm{C}_{\mathrm{Q}}\right|$ (MHz) & $m_{\mathrm{Q}} \mid$ \\
\hline \multirow[t]{4}{*}{ Monomer } & B3LYP & 199.57 & 36.73 & 1.07 & 0.69 \\
\hline & M062X & 205.94 & 32.31 & 1.03 & 0.68 \\
\hline & M06L & 205.93 & 33.56 & 1.01 & 0.75 \\
\hline & CAM-B3LYP & 204.35 & 35.15 & 1.08 & 0.67 \\
\hline \multirow[t]{4}{*}{ Dimer } & B3LYP & 200.67 & 34.46 & 1.00 & 0.66 \\
\hline & M062X & 207.47 & 28.40 & 0.96 & 0.65 \\
\hline & M06L & 205.56 & 31.11 & 0.94 & 0.72 \\
\hline & CAM-B3LYP & 205.49 & 32.86 & 1.01 & 0.64 \\
\hline \multirow[t]{4}{*}{ Trimer } & B3LYP & 201.00 & 32.72 & 0.94 & 0.61 \\
\hline & M062X & 207.81 & 26.64 & 0.90 & 0.60 \\
\hline & M06L & 206.26 & 30.39 & 0.88 & 0.68 \\
\hline & CAM-B3LYP & 205.98 & 31.19 & 0.95 & 0.59 \\
\hline \multirow[t]{4}{*}{ Tetramer } & B3LYP & 200.95 & 32.50 & 0.93 & 0.60 \\
\hline & M062X & 207.75 & 26.43 & 0.89 & 0.59 \\
\hline & M06L & 206.39 & 28.96 & 0.87 & 0.67 \\
\hline & CAM-B3LYP & 205.96 & 31.07 & 0.94 & 0.58 \\
\hline \multirow[t]{4}{*}{ Pentamer } & B3LYP & 200.93 & 32.30 & 0.93 & 0.60 \\
\hline & M062X & 207.96 & 25.98 & 0.89 & 0.58 \\
\hline & M06L & 206.32 & 28.60 & 0.86 & 0.66 \\
\hline & CAM-B3LYP & 205.99 & 30.88 & 0.94 & 0.58 \\
\hline
\end{tabular}

acids, hence, we can determine any changes in the structure of ion channels.

\section{2. Computational Errors}

Usually the magnitude of $\mathrm{C}_{\mathrm{Q}}\left({ }^{35} \mathrm{Cl}\right)$ measured from NMR spectra of chloride ions in organic and inorganic salts range from essentially zero in cubic salts to greater than $9.0 \mathrm{MHz},{ }^{41,42}$ and the results of the calculations of the chlorine-35 quadrupolar coupling constants measured in this study were in this range. According to available experimental data for chlorine nucleus, ${ }^{25,43}$ we can compare four methods used for calculating NQR parameters in these two amino acids. By comparing the experimental and

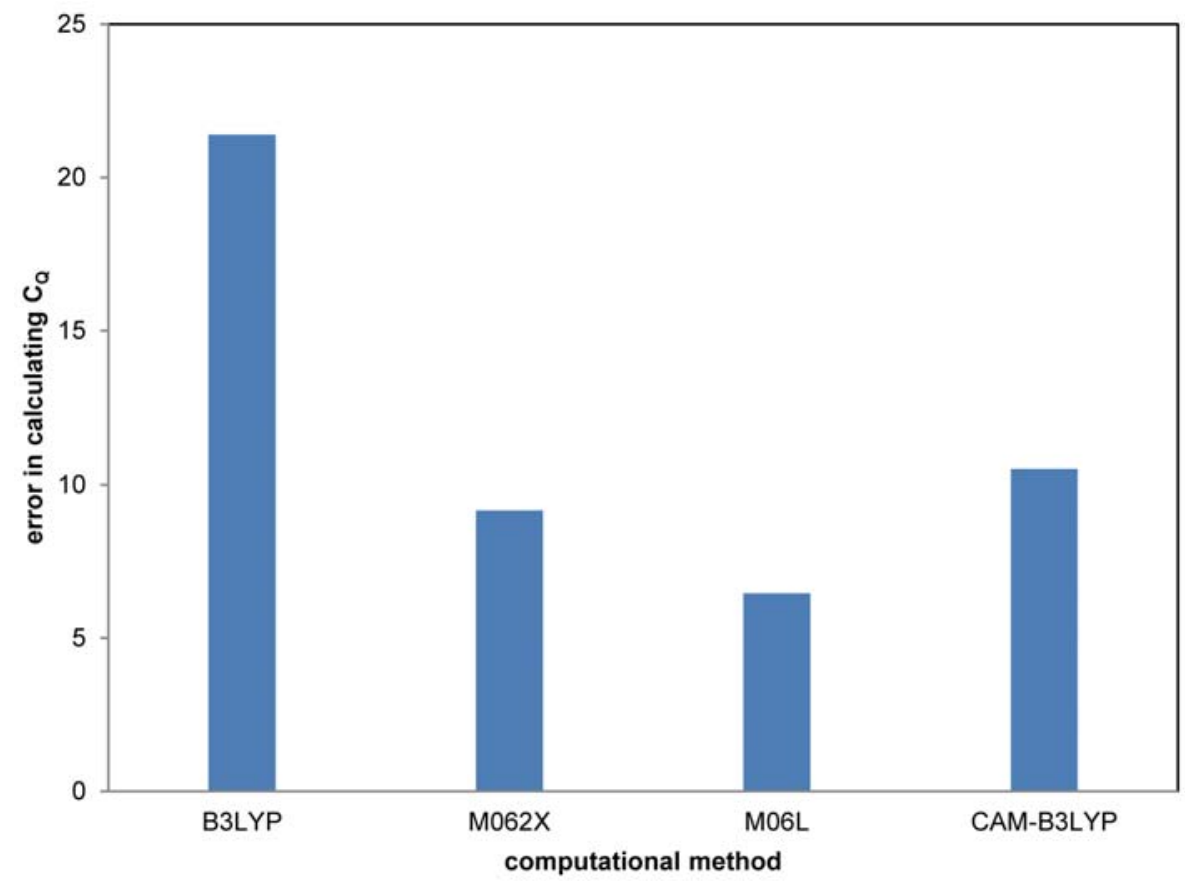

Figure 3. Comparison of computational methods used in calculation 35Cl CQ of both hydrochloride salts. 
calculated values shown in Tables 1 and 3, the M06L/6$311++\mathrm{G}(\mathrm{d}, \mathrm{p})$ method is more accurate and has the lowest computational error for calculating $\mathrm{C}_{\mathrm{Q}}$ in these molecules. Figure 3 shows the average of errors calculated for two hydrochloride salts.

According to available NMR experimental data for chlorine nuclei, ${ }^{43}$ percent errors in calculating $\sigma_{\text {iso }}$ of the chlorine nucleus in alanine hydrochloride salt for B3LYP, M06-2X, M06L, CAM-B3LYP functional were 3.10\%, $3.23 \%, 2.69 \%$, and $4.71 \%$, respectively, and for threonine hydrochloride were $12.74 \%, 15.32 \%, 11.82 \%$, and $14.84 \%$, respectively. So, we can see again that the M06L/6- 311++G(d,p) method was the most accurate method in these two amino acids.

\section{3. Correlation Between NMR and NBO Parameters}

Changes in anisotropy parameter are correlated to the NBO parameters. Chemical shielding anisotropy of ni-

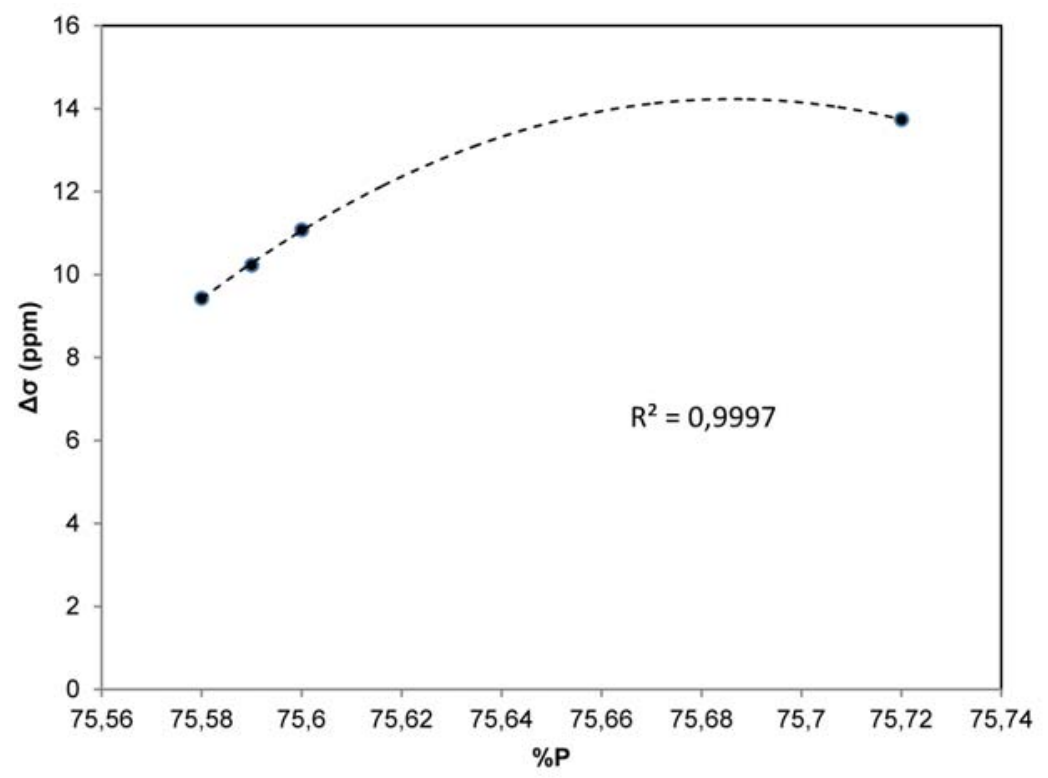

Figure 4. Correlation between percent of $\mathrm{P}$ orbital and $\Delta \sigma$ in alanine hydrochloride salt.

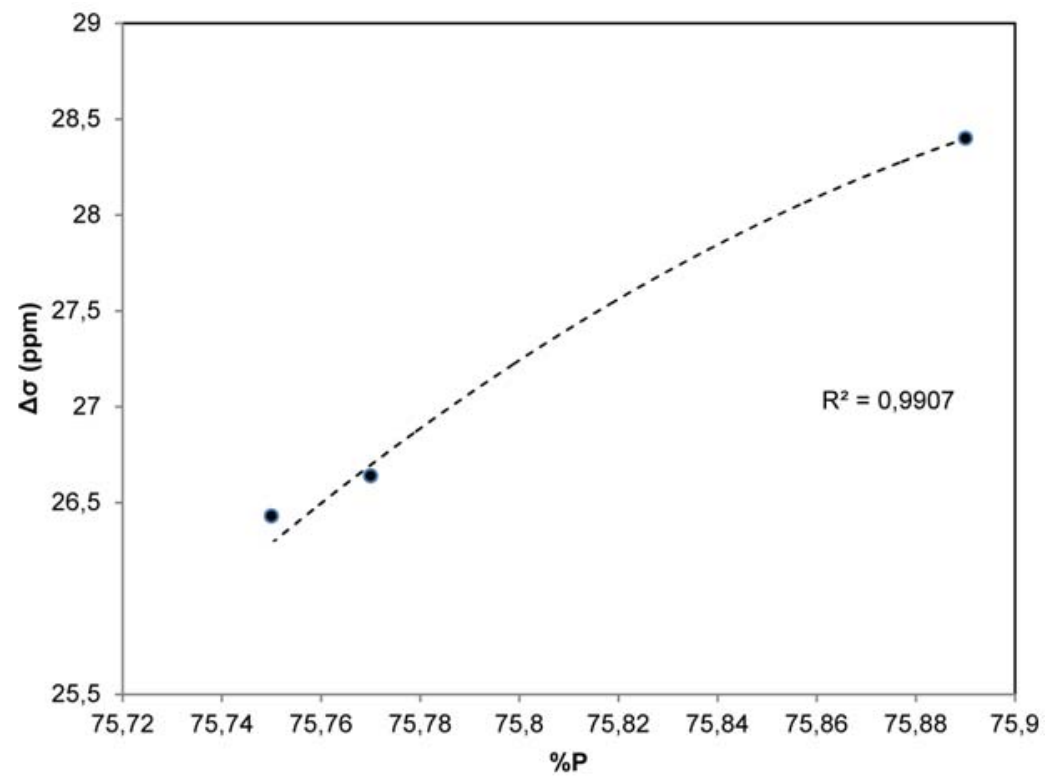

Figure 5. Correlation between percent of $\mathrm{P}$ orbital and $\Delta \sigma$ in threonine hydrochloride salt. 
Table 5. NBO analysis of $\mathrm{NH}(1)-\mathrm{Cl}$ interaction for alanine hydrochloride clusters calculated with M06-2X/6-311++G(d,p) method.

\begin{tabular}{|c|c|c|c|c|c|c|}
\hline Model & $\mathrm{E}_{\mathrm{NBO}}(\mathrm{kCal} / \mathrm{mol})$ & $\mathbf{n}_{\mathrm{Cl}}$ & $\sigma_{\dot{\mathbf{N}}-\mathbf{H}}$ & \% S Character & $\%$ Polarization & $\% \mathbf{P}$ \\
\hline 1 & 52.58 & $\mathrm{sp}^{0.12}$ & $0.4445 \mathrm{sp}^{2.92}-0.8958 \mathrm{~s}$ & 25.48 & 74.49 & 74.49 \\
\hline 2 & 43.47 & $\mathrm{sp}^{0.14}$ & $0.4552 \mathrm{sp}^{3.12}-0.8904 \mathrm{~s}$ & 24.24 & 75.72 & 75.72 \\
\hline 3 & 35.32 & $\mathrm{sp}^{0.38}$ & $0.4684 \mathrm{sp}^{3.10}-0.8835 \mathrm{~s}$ & 24.36 & 75.60 & 75.60 \\
\hline 4 & 33.64 & $\mathrm{sp}^{0.38}$ & $0.4704 \mathrm{sp}^{3.10}-0.8824 \mathrm{~s}$ & 24.38 & 75.59 & 75.59 \\
\hline 5 & 32.84 & $\mathrm{sp}^{0.38}$ & $0.4712 \mathrm{sp}^{3.10}-0.8820 \mathrm{~s}$ & 24.37 & 75.58 & 75.58 \\
\hline
\end{tabular}

Table 6. NBO analysis of NH-Cl interaction for threonine hydrochloride clusters calculated with M06-2X/6-311++G(d,p) method.

\begin{tabular}{|c|c|c|c|c|c|c|}
\hline Model & $\mathrm{E}_{\mathrm{NBO}}(\mathrm{kCal} / \mathrm{mol})$ & $\mathbf{n}_{\mathrm{Cl}}$ & $\sigma_{\dot{\mathrm{N}}-\mathrm{H}}$ & \% S Character & $\%$ Polarization & $\% \mathbf{P}$ \\
\hline 1 & 50.32 & $\mathrm{sp}^{0.11}$ & $0.4646 \mathrm{sp}^{2.94}-0.8998 \mathrm{~s}$ & 25.31 & 80.96 & 74.66 \\
\hline 2 & 40.87 & $\mathrm{sp}^{0.14}$ & $0.4753 \mathrm{sp}^{3.14}-0.8934 \mathrm{~s}$ & 24.07 & 79.82 & 75.89 \\
\hline 3 & 32.63 & $\mathrm{sp}^{0.40}$ & $0.4885 \mathrm{sp}^{3.12}-0.8875 \mathrm{~s}$ & 24.19 & 78.77 & 75.77 \\
\hline 4 & 31.83 & $\mathrm{sp}^{0.41}$ & $0.4905 \mathrm{sp}^{3.11}-0.8864 \mathrm{~s}$ & 24.21 & 78.57 & 75.75 \\
\hline 5 & 31.52 & $\mathrm{sp}^{0.41}$ & $0.4913 \mathrm{sp}^{3.11}-0.8860 \mathrm{~s}$ & 24.22 & 78.50 & 75.74 \\
\hline
\end{tabular}

trogen atom in alanine hydrochloride decreases with increasing cluster size. According to Table 5, hybridization of nitrogen atom changes from $\mathrm{SP}^{3.12}$ to $\mathrm{SP}^{3.10}$, this increase in s character and decrease in $\mathrm{p}$ character cause the electronic cloud around the nucleus to become more symmetric, and chemical shielding anisotropy subsequently decreases. Similarly, a nitrogen atom in threonine hydrochloride changes from $\mathrm{SP}^{3.14}$ to $\mathrm{SP}^{3.11}$, so the symmetry around the nucleus increases, and the anisotropy parameter decreases, as shown in Tables 4 and 6, and Figures 4 and 5.

\section{4. Analysis of Structural Parameters}

In this study we have investigated $\mathrm{NH}-\mathrm{Cl}$ hydrogen bond in crystal lattice. Two effects influence the A-H-B hydrogen bond: the hyperconjugative effect that decreases the strength of $\mathrm{A}-\mathrm{H}$ bond and subsequently increases the length of the A-H bond, and the rehybridization effect that leads to an increase in the A-H bond strength that then decreases the A-H bond length. ${ }^{44}$ The hyperconjugative effect is connected with the energy of electron charge transfer, $\mathrm{E}_{\mathrm{NBO}}$, and will increase if this energy in-

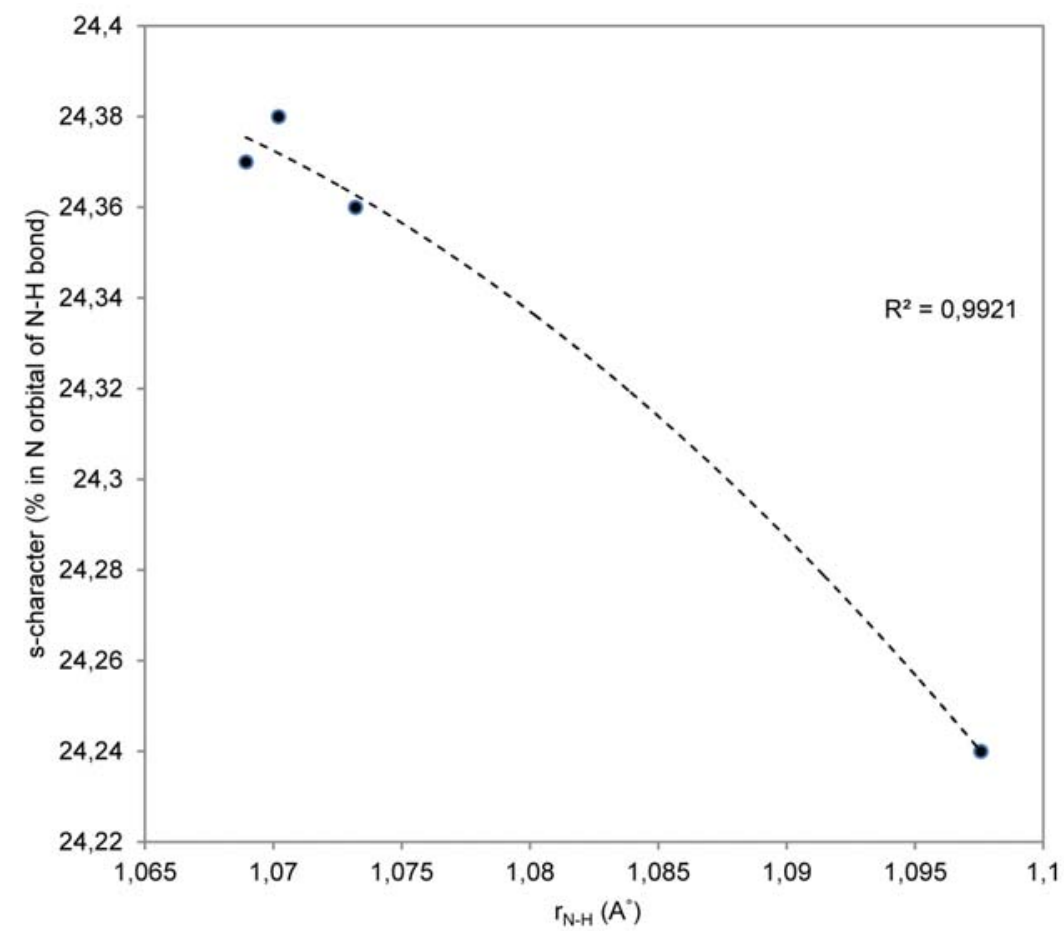

Figure 6. correlation between s-character and N-H bond length for N-H-Cl interaction in alanine hydrochloride salt. 


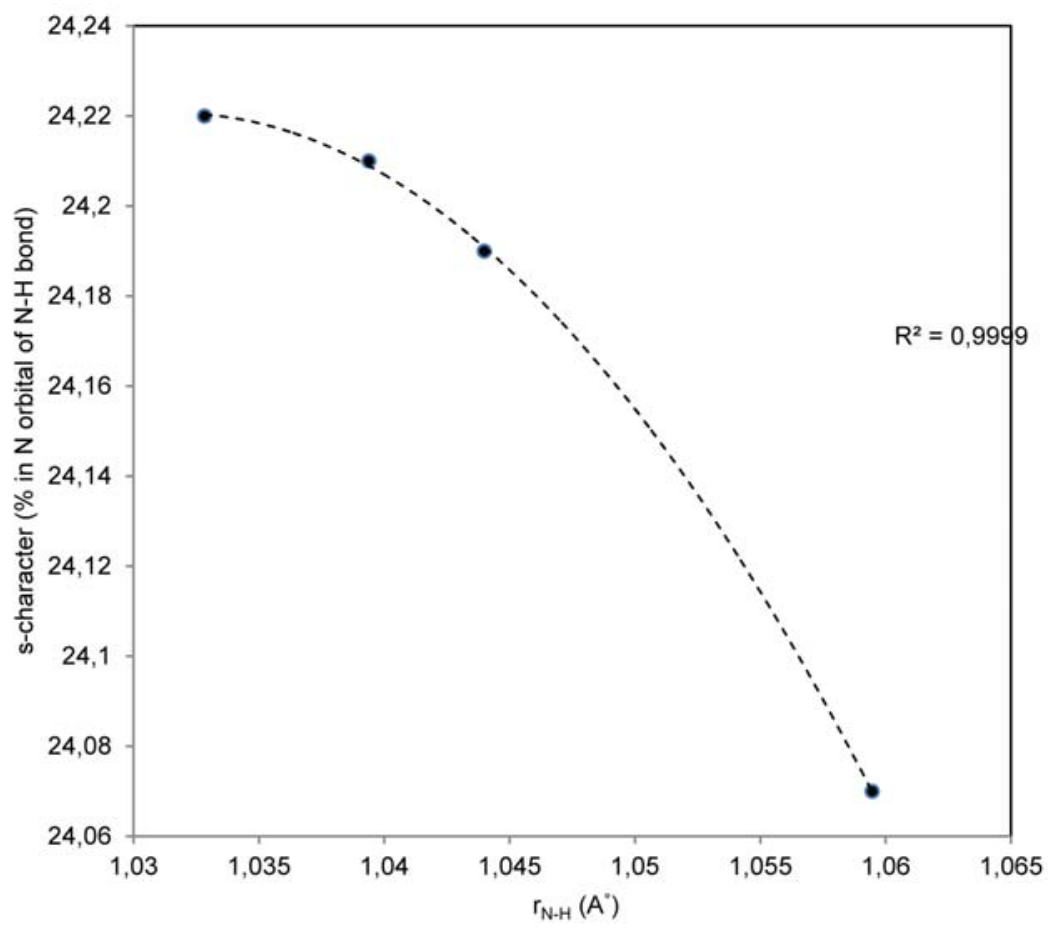

Figure 7. correlation between s-character and $\mathrm{N}-\mathrm{H}$ bond length for $\mathrm{N}-\mathrm{H}--\mathrm{Cl}$ interaction in threonine hydrochloride salt.

Table 7. Structural parameters for Alanine hydrochloride clusters optimized with M06-2X/6-31++G(d,p) method.

\begin{tabular}{ccc}
\hline Model & $\mathbf{r}_{\mathbf{N}-\mathbf{H}}(\AA$ & $\mathbf{r}_{\mathbf{H}-\mathrm{Cl}}(\AA)$ \\
\hline 1 & 1.123 & 2.075 \\
2 & 1.098 & 2.101 \\
3 & 1.073 & 2.127 \\
4 & 1.070 & 2.131 \\
5 & 1.069 & 2.132 \\
\hline
\end{tabular}

Table 8. Structural parameters for Threonine hydrochloride clusters optimized with M06-2X/6-31++G(d,p) method.

\begin{tabular}{ccc}
\hline Model & $\mathbf{r}_{\mathrm{N}-\mathrm{H}}(\AA$ & $\mathbf{r}_{\mathrm{H}-\mathrm{Cl}}(\AA)$ \\
\hline 1 & 1.085 & 2.109 \\
2 & 1.059 & 2.135 \\
3 & 1.044 & 2.161 \\
4 & 1.039 & 2.165 \\
5 & 1.033 & 2.167 \\
\hline
\end{tabular}

creases. The s-character of the A-atom hybrid orbital in the $\mathrm{A}-\mathrm{H}$ bond is directly dependent to the rehybridization process. The structural parameters for alanine hydrochloride are presented in Table 7. According to Table 5, s-character from dimer to pentamer increases from 24.24 to 24.37 , but $\mathrm{E}_{\mathrm{NBO}}$ decreases from 43.47 to $35.32 \mathrm{kcal} / \mathrm{mol}$. Therefore, in this interaction, we expect that $\mathrm{NH}$ bond length decreases from dimer to pentamer, the accuracy of which can be inferred from Table 7. Similarly, for threo- nine hydrochloride, as evident from Table 8 , the NH bond length decreases from $1.059 \AA$ to $1.033 \AA$. The rehybridization effect simultaneously increases, as shown in Table 6 , due to reduction in $\mathrm{E}_{\mathrm{NBO}}$ and increase in s-character. These correlations have been represented in Figures 6 and 7.

\section{Conclusions}

The EFG and the chemical shielding tensors have been calculated for chlorine and nitrogen nuclei, via the following four functionals: B3LYP, M062X, M06L, and CAMB3LYP and with $6-311++\mathrm{G}(\mathrm{d}, \mathrm{p})$ basis set. The aim of this study was to demonstrate the sensitivity of NMR interaction tensors to slight differences in the local environment at every nucleus where there was a $\mathrm{NH}-\mathrm{Cl}$ hydrogen bond. This matter is so crucial because it illustrates the changes in ion channel structure, whereby the NMR and NQR parameters are significantly changed when the structures of the monomer transform to pentamer. The results agree with experimental data, which illustrates that the M06L/6-311++G(d,p) method is the most accurate method for NMR and NQR calculations in these two amino acids. In addition, it is shown that there was a high correlation between NMR parameters and NBO parameters, and between structural parameters and NBO parameters.

Information from NMR, NQR, and NBO analysis are useful for interpretation of the structure in both solu- 
tion and solid states. These techniques are especially useful for biological molecules such as proteins and also for larger systems with unknown structure.

\section{References}

1. J. S. Murray, M. C. Concha, P. Lane, P. Hobza, P. Politzer, Blue shifts vs red shifts in $\sigma$-hole bonding, J. Mol. Model., 2008, 14, 699-704. http://dx.doi.org/10.1007/s00894-008-0307-y

2. S. Scheiner, Hydrogen bonding: a theoretical perspective, Oxford University Press, New York, 1997.

3. M. Esrafili, H. Behzadi, NL. Hadipour, Density functional theory study of $\mathrm{N}-\mathrm{H}-\mathrm{O}, \mathrm{O}-\mathrm{H}-\mathrm{O}$ and $\mathrm{C}-\mathrm{H}-\mathrm{O}$ hydrogenbonding effects on the ${ }^{14} \mathrm{~N}$ and ${ }^{2} \mathrm{H}$ nuclear quadrupole coupling tensors of N-acetyl-valine, Biophys. Chem., 2008, 133, 11-18. http://dx.doi.org/10.1016/j.bpc.2007.11.006

4. H. Behzadi, MD. Esrafili, NL. Hadipour, A theoretical study of ${ }^{17} \mathrm{O},{ }^{14} \mathrm{~N}$ and ${ }^{2} \mathrm{H}$ nuclear quadrupole coupling tensors in the real crystalline structure of acetaminophen, Chem. Phys., 2007, 333, 97-104. http://dx.doi.org/10.1016/j.chemphys.2007.01.011

5. S. J. Grabowski, W. A. Sokalski, E. Dyguda, J. Leszczyńki, Quantitative classification of covalent and noncovalent $\mathrm{H}$ bonds, Phys. Chem. B, 2006, 110, 6444-6446. http://dx.doi.org/10.1021/jp0600817

6. M. D. Esrafili, A theoretical investigation of the characteristics of hydrogen/ halogen bonding interactions in dibromonitroaniline, J. Mol. Model., 2012, 19, 1417-1427. http://dx.doi.org/10.1007/s00894-012-1691-x

7. R. H. Holm and E. I. Solomon, Chem. Rev., 1996, 96, 22372238 (thematic issue). http://dx.doi.org/10.1021/cr9500390

8. C. Ceccarelli, G. A. Jeffrey, R. Taylor, A survey of O-H-O hydrogen bond geometries determined by neutron diffraction, J. Mol. Struct., 1981, 70, 255-271. http://dx.doi.org/10.1016/0022-2860(81)80112-3

9. G. A. Jeffrey, W. Saenger, Hydrogen Bonding in Biological Structures, Springer-Verlag, Berlin, 1991. http://dx.doi.org/10.1007/978-3-642-85135-3

10. T. Steiner, W. Saenger, Geometry of C-H-O hydrogen bonds in carbohydrate crystal structures, Analysis of neutron diffraction data, J. Am. Chem. Soc., 1992, 114, 10146-10154. http://dx.doi.org/10.1021/ja00052a009

11. T. Steiner, W. Saenger, Role of C-H-O hydrogen bonds in the coordination of water molecules, Analysis of neutron diffraction data, J. Am. Chem. Soc., 1993, 115, 4540-4547. http://dx.doi.org/10.1021/ja00064a016

12. D. Braga, R. Grepioni, K. Biradha, V. R. Pedireddi, G. R. Desiraju, Hydrogen bonding in organometallic crystals, 2. $\mathrm{C}-\mathrm{H}-\mathrm{O}$ hydrogen bonds in bridged and terminal first-row metal carbonyls, J. Am. Chem. Soc., 1995, 117, 3156-3166. http://dx.doi.org/10.1021/ja00116a020

13. W. B. Guggino, Ion Chloride Channels: Current Topics in Membranes, A. Kleinzeller, D.M. Fambrough, Eds., Academic Press, San Diego, 1994, 42.
14. F. M. Ashcroft, Ion Channels and Disease, Academic Press, San Diego, 2000.

15. M. E. Loewen, G. W. Forsyth, Structure and Function of CLCA Proteins, Physiol. Rev., 2005, 85, 1061-1092. http://dx.doi.org/10.1152/physrev.00016.2004

16. T. J. Jentsch, T. Maritzen, A. A. Zdebik, Chloride channel diseases resulting from impaired transepithelial transport or vesicular function, J. Clin. InVest., 2005, 115, 2039- 2046. http://dx.doi.org/10.1172/JCI25470

17. R. Dutzler, E. B. Campbell, R. MacKinnon, Gating the Selectivity Filter in ClC Chloride Channels, Science, 2003, 300, 108- 112 .

http://dx.doi.org/10.1126/science.1082708

18. S. B. Long, E. B. Campbell, R. MacKinnon, Crystal Structure of a Mammalian Voltage-Dependent Shaker Family $\mathrm{K}^{+}$ Channel, Science, 2005, 309, 897-903. http://dx.doi.org/10.1126/science.1116269

19. E. A. C. Lucken, Nuclear Quadrupole Coupling Constants, Academic Press, London, 1969.

20. A. Bax, Weak alignment offers new NMR opportunities to study protein structure and dynamics, Protein Sci., 2003, 12, 1-16. http://dx.doi.org/10.1110/ps.0233303

21. P. M. Hwang, L. E. Kay, Solution structure and dynamics of integral membrane proteins by NMR: A case study involving the enzyme PagP, Methods Enzymol., Part C, 2005, 394, 335-350. http://dx.doi.org/10.1016/s0076-6879(05)94013-5

22. S. G. Zech, A. J. Wand, A. E. McDermott, Protein structure determination by high-resolution solid-state NMR spectroscopy: Application to microcrystalline ubiquitin, J. Am. Chem. Soc., 2005, 127, 8618-8626. http://dx.doi.org/10.1021/ja0503128

23. C. P. Jaroniec, C. E. MacPhee, V. S. Bajaj, M. T. McMahon, C. M. Dobson, R. G. Griffin, High-resolution molecular structure of a peptide in an amyloid fibril determined by magic angle spinning nmr spectroscopy, Proc. Natl. Acad. Sci. U.S.A., 2004, 101, 711-716. http://dx.doi.org/10.1073/pnas.0304849101

24. D. L. Bryce, M. Gee, R. E. Wasylishen, High-field chlorine NMR spectroscopy of solid organic hydrochloride salts: A sensitive probe of hydrogen bonding environment, J. Phys. Chem. A, 2001, 105, 10413-10421. http://dx.doi.org/10.1021/jp011962a

25. R. P. Chapman, D. L. Bryce, A high-field solid-state ${ }^{35 / 37} \mathrm{Cl}$ NMR and quantum chemical investigation of the chlorine quadrupolar and chemical shift tensors in amino acid hydrochlorides, Phys. Chem. Chem. Phys., 2007, 9, 62196230. http://dx.doi.org/10.1039/b712688c

26. J. R. Yates, C. J. Pickard, F. Mauri, Calculation of NMR chemical shifts for extended systems using ultrasoft pseudopotentials, Phys. Rev. B., 2007, 76.

http://dx.doi.org/10.1103/physrevb.76.024401

27. P. Chananont, T. A. Hamor, stereochemistry of anticholinergic agents. XV. Structure of 2-(diethylamino)ethyl 1-cyclohexylcyclohexanecarboxylate hydrochloride (dicyclomine hydrochloride), Acta Crystallogr., Sect. B: Struct. Sci., 1981, 37, 1878-1881. 
http://dx.doi.org/10.1107/S0567740881007462

28. R. Kingsfordadaboh, E. Hayashi, M. Haisa, S. Kashino, Crystal-structures and molecular-conformations of isoprenaline hydrochloride and (s)-isoprenaline hydrogen (2R,3R)-tartrate, Bull. Chem. Soc. Jpn., 1993, 66, 2883-2888. http://dx.doi.org/10.1246/bcsj.66.2883

29. J. N. Latosinska, A correlation of spectroscopic parameters from different magnetic resonance spectroscopies for thiazides: a study by NQR, NMR, EPR and DFT methods, Chem. Phys. Lett., 2004, 398, 324-329. http://dx.doi.org/10.1016/j.cplett.2004.09.088

30. Remya Karunakaran, H. Suresh Cherumuttathu, Which density functional is close to CCSD accuracy to describe geometry and intraction energy of small noncovalent dimmers? A benchmark study using Gaussian09, Comp. Chem., 2013, 34, 1341-1353. http://dx.doi.org/10.1002/jcc.23263

31. Y. Zhao, D. G. Truhlar, The M06 suite of density functionals for main group thermochemistry, kinetics, noncovalent interactions, excited states, and transition elements: two new functionals and systematic testing of four M06 functionals and twelve other functionals, Theor. Chem. Acc., 2008, 120, 215-241. http://dx.doi.org/10.1007/s00214-007-0310-x

32. Y. Zhao, D. G. Truhlar, A new local density functional for main-group thermochemistry, transition metal bonding, thermochemical kinetics, and noncovalent interactions, J. Chem. Phys., 2006, 125, 194101. http://dx.doi.org/10.1063/1.2370993

33. U. Haeberlen, Advances in Magnetic Resonance, Supplement 1, Academic Press, New York, 1976.

34. H. W. Spiess, Rotation of molecules and nuclear spin relaxation, in: P. Diehl, E. Fluck, Kosfeld, (Eds.), NMR Basic Principles and Progress, Springer- Velag, Berlin, 1978, 15, 55-214. http://dx.doi.org/10.1007/978-3-642-66961-3_2

35. J. Sławomir, Grabowski, Hydrogen and halogen bonds are ruled by the same mechanisms, Phys.Chem. Chem. Phys., 2013, 15, 7249. http://dx.doi.org/10.1039/c3cp50537e

36. S. J. Grabowski, What is the covalency of hydrogen bonding?, Chem.Rev., 2011, 111, 2597-2625. http://dx.doi.org/10.1021/cr800346f

37. H. A. Bent, An appraisal of valence-bond structures and hybridization in compounds of the first-row elements, Chem.Rev., 1961, 61, 275-311.

http://dx.doi.org/10.1021/cr60211a005

38. M. W. Schmidt, K. K. Baldridge, J. A. Boatz, S. T. Elbert, M. S. Gordon, J. H. Jensen, S. Koseki, N. Matsunaga, K. A. Nguyen, S. J. Su, T. L. Windus, M. Dupuis, J. A. Montgomery, General Atomic and Molecular Electronic Structure System, J. Comput. Chem., 1993, 14, 1347- 1363. http://dx.doi.org/10.1002/jcc.540141112

39. B. Di Blasio, V. Pavone and C. Pedone, Cryst. Struct. Commun., 1977, 6, 745-748.

40. Kazuo Yamauchi, Shigeki Kuroki, Isao Ando, Takuo Ozaki, Akira Shoji, ${ }^{17} \mathrm{O}$ NMR chemical shifts and quadrupole coupling constants in solid poly(L-alanine)s determined using a high-speed MAS technique, Chem. Phys. Let., 1999, 331336.

41. T. O. Sandland, L. S. Du, J. F. Stebbins and J. D. Webster, Structure of Cl-containing silicate and aluminosilicate glasses: A ${ }^{35} \mathrm{Cl}$ MAS-NMR study, Geochim. Cosmochim. Acta, 2004, 68, 5059-5069. http://dx.doi.org/10.1016/j.gca.2004.07.017

42. S. Hayashi and K. Hayamizu, Accurate determination of NMR chemical shifts in alkali halides and their correlation with structural factors, Bull. Chem. Soc. Jpn., 1990, 63, 913919. http://dx.doi.org/10.1246/bcsj.63.913

43. Christel Gervais, Ray Dupree, Kevin J. Pike, Christian Bonhomme, Mickaell Profeta, Chris J. Pickard, Francesco Mauri, Combined first-principles computational and experimental multinuclear solid-state NMR investigation of amino acids, J. Phys. Chem. A, 2005, 109, 6960-6969. http://dx.doi.org/10.1021/jp0513925

44. I. V. Alabugin, M. Manoharan, S. Peabody and F. Weinhold, Electronic basis of improper hydrogen bonding: a subtle balance of hyperconjugation and rehybridization, J. Am. Chem. Soc., 2003, 125, 5973-5987. http://dx.doi.org/10.1021/ja034656e

\section{Povzetek}

$\mathrm{S}$ kvantno mehanskimi izračuni smo proučevali $\mathrm{NH}-\mathrm{Cl}$ vodikove vezi hidrokloridnih soli dveh amino kislin, alanina in treonina. S pomočjo štirih funkcionalov, B3LYP, M062X, M06L, CAM-B3LYP in z uporabo 6-311++G(d,p) baznega seta smo izračunali resonančne parametre za nuklearno magnetno resonance in nuklearno kvadropolno resonanco. $Z$ M062X/6-31++G(d,p) metodo in analizo veznih orbital z uporabo M062X/6-311++G(d,p) nivoja smo izvedli geometrijsko optimizacijo. Resonančni parametri kažejo možne strukture od monomer do pentamer, povezo med njimi in parametri veznih orbital pa smo uporabili za študij možne tvorbe kristalov. 